\title{
The Value Relevance Of Value Added And Stakeholder Compensation Across Business Cultures
}

\author{
John Darcy, (Email: johndarcy@utpa.edu), University of Texas, Pan American
}

\begin{abstract}
This research performed a partial test of the instrumental validity of the stakeholder model by examining the value relevance of value added relative to income and the incremental value relevance of two stakeholder compensation components of value added, wages and interest for Japan, Germany, United States, and United Kingdom.
\end{abstract}

\section{INTRODUCTION}

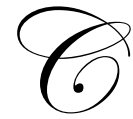

onsiderable attention has been devoted by researchers and analysts in developing and testing alternatives to accounting income that might better represent the economic performance of the company in equity valuation models. Stakeholder theory provides a framework for examining the connections between the management of stakeholder resources and shareholder value and can be used as a basis for empirical testing. This theory describes the corporation as a combination of cooperative and competitive stakeholder interests, including shareholders, employees, lenders, and government, each possessing intrinsic value. It argues that that there is no prima facie priority of benefits to one group of stakeholders over another, and the satisfaction of multiple stakeholders need not be a zero sum game, i.e., that benefits to one stakeholder group need not come entirely at the expense of another (Preston \& Sapienza 1990).

Large firms in Japan and Germany are characterized as following stakeholder governance models and having the objective of maximizing value added (Yoshimori 1996, M. M. Blair 1995:322). In contrast, companies in the United States and United Kingdom (Anglo-American companies) are generally viewed as short-term profit maximizers which follow a shareholder model of corporate governance. Value added is a summary accounting measure of the wealth created during the period by a firm that reflects compensation to both the equity stakeholders (the shareholders) and the non-equity stakeholders, including employees, lenders, and government. It may be calculated by adding wages, interest, and taxes back to income.

Value added may be considered a longer-term signal of value than earnings because investments in firmspecific stakeholder intangibles reflected in value added, particularly investments in human capital, create benefits that are expected to converge with shareholder returns only in the long term. In calculating accounting earnings these investments are expensed rather than counted as assets. From a stakeholder theory perspective, accounting earnings are a poor proxy for value because the treatment of investments in stakeholder intangibles as expenses understates true earnings, and a focus on current earnings by investors and managers penalizes the multiperiod investments needed to build skills and market position (Porter 1992).

Long-term accounting measures are generally regarded as less value relevant for Anglo-American companies than for companies in Japan or Germany because of differences in the makeup of their investors. Share ownership in Anglo-American companies tends to be dominated by short-term, transaction-driven investors who hold relatively small interests in the company and who have little direct influence on management. Information asymmetries between managers and investors in these companies result in the use of simple value proxies, such as current earnings, being used for valuation purposes. Japanese and German companies tend to have dominant investors which are permanent, relationship-driven owners holding large stakes in the company. These investors are motivated to 
accumulate knowledge on long-term corporate prospects and exert more influence on management (Porter 1992). In Japanese and German companies, direct information transfers between managers and investors are credited with creating longer-term investment horizons (Poterba and Summers 1992, Renneboog 1999). These lower information asymmetries in Japanese and German firms are credited with providing managers in those countries with the greater ability to maximize value added and create shareholder value through long-term investments. In particular, investment by Japanese and Germany firms in human capital has been observed to be significantly higher than that of U.S. firms (Farb 1992, Kochan and Osterman 1992), Blinder and Krueger 1992).

This paper provides an empirical examination of the valuation usefulness of value added and related stakeholder compensation information in two shareholder-oriented countries, the U.S. and U.K., and two stakeholderoriented countries, Japan and Germany. Although there is substantial research attesting to the descriptive and normative validity of the stakeholder model (M.M. Blair 1995, Porter 1992, Freeman 1984), there has been very little empirical testing of its instrumental validity (Donaldson and Preston 1995). By limiting the inquiry to the impact on shareholders, this paper performs a partial test of the instrumental validity of the stakeholder model. It examines the value relevance of value added relative to income and the incremental value relevance of two stakeholder compensation components of income: employee compensation and interest.

Three main questions are addressed in this paper. First, does empirical evidence support the stakeholder theory that value added has relatively more value relevance than earnings in any of the four countries examined? Second, proceeding from the theory that, due to higher degrees of information asymmetry, long-term accounting measures are relatively less value relevant for Anglo-American companies than for companies in Japan or Germany, is value added more value relevant in either Japan or Germany than in either the U.S. or U.K.?

The third question addresses whether value added stakeholder compensation in the form of employee compensation and/or interest expense provides incremental value relevance beyond earnings in any of the four countries. The incremental tests addressing this third question apply stakeholder theory to the valuation question by disaggregating income into components which accrue to non-equity stakeholders versus the shareholders. This approach also makes it possible to estimate whether a portion of non-equity stakeholder compensation incurred as wages and interest is considered by investors to represent an investment in intangible human capital or interest costs, and whether, as stakeholder theory suggests, earnings and asset values are understated in financial reports. Crosscountry comparisons provide information of an exploratory nature regarding the differing value relevance of these intangibles in the four countries studied in this paper.

Prior research involving the value relevance of value added based on U.S. data has generally concluded that value added is more value relevant (or has more information content) than net income (Riahi-Belkaoui 1993, RiahiBelkaoui and Picur 1994, Bao and Bao 1998). However, the samples of U.S. companies used in these studies may not be representative of Anglo-American companies in general. For example, data requirements in the Bao and Bao (1998) study limited their sample to 166 firms out of the more than ten thousand in the COMPUSTAT database. I use virtually all large, non-financial companies from the U.K., Japan, and Germany to make up the samples in this paper. As in prior research, data requirements limit my U.S. sample to only a small percentage (less than six percent) of the non-financial companies in the Compustat database. Given that the quality of U.K. accounting data has been established (Alford et al. 1993) and the economic environments and business cultures are similar in the U.S. and U.K., the sample of U.K. companies in this paper may be more representative of Anglo-American companies in general than the small sample of U.S. companies.

Although maximization of value added is not the objective of Anglo-American firms, stakeholder theory is increasingly used to influence business policy in both the U.S. and U.K. ${ }^{1}$ The valuation implications of value added are therefore important to Anglo-American firms which are experiencing social and political pressure to expand the

\footnotetext{
${ }^{1}$ Kotter and Heskett's (1992:59) case studies of a small number of high performance U.S. companies indicate that the managers of those companies tend to emphasize the interests of all major stakeholder groups in their decision making. In the U.K., Prime Minister Blair has called for the development of a "stakeholder economy," characterized by an investment in employees who are regarded as a source of innovation and not just a factor of production (Blair, T. 1996).
} 
scope of stakeholder considerations included in their decision making. ${ }^{2}$ The scarcity of employee information for U.S. companies hampers the use of the methods described in this paper. Increased disclosure of employee compensation by U.S. companies would also bring the U.S. more into line with the reporting practices of other developed countries. But U.S. companies may be justified in not reporting value added or employee compensation information if this information is less value relevant for Anglo-American companies than for companies in other countries.

Results from the relative value relevance tests for the U.K. sample firms demonstrate significantly more value relevance for income than for value added among U.K. companies. Income of these U.K. companies is also shown to be more value relevant than either income or value added of each of the other countries in the study. Value added is not shown to be more value relevant in stakeholder countries than shareholder countries or more value relevant than income in cross-country tests. In particular, the value added of Japanese and Germany companies is not shown to be more value relevant than either income or value added of U.S. or U.K. companies. On the contrary, value added of U.S. and U.K. firms tends to show more value relevance than the value added of Japanese or German companies.

The next section of this paper describes the research design and hypotheses used to address the research questions. Following sections describe the data used, econometric issues, and the results of the tests. A summary and conclusion is given in the last section.

\section{RESEARCH DESIGN AND HYPOTHESES}

\section{Relative Value Relevance Of Value Added And Income}

Accounting theory suggests that earnings at least nominally provides a link to shareholder value because, if the clean surplus assumption is satisfied, it summarizes both the line items in the income statement and changes in the balance sheet (Penman 1992). In contrast, value added ignores important expenses that may account for a considerable portion of revenues. Hence, value added overstates the benefits equity holders receive from current period operations. But it is an empirical question as to which measure has better associations with value. Interestingly, prior studies using U.S. data consistently show superior relative value relevance (or information content) for value added over income (Riahi-Belkaoui 1993, Riahi-Belkaoui and Picur 1994, Bao and Bao 1998). Because these studies were limited to the few U.S. companies which report the employee compensation data needed to compute value added, it is possible that these results are influenced by self-selection bias.

I evaluate the relative value relevance of value added and income for the four countries in this study using the lack of fit measure devised by Biddle, Seow, and Siegel (1995) [hereinafter "BSS"] and $\overline{\mathrm{R}}^{2}$ statistics. This measure is appropriate asymptotically in the presence of heteroscedasticity, assuming the disturbances of the regression equations are distributed normally with mean zero and unknown covariance matrix. As represented by equation (1), this is a lack of fit measure defined as the average of the sum of squared residuals and the sum of squared prediction errors.

$\Theta=B_{2}^{\prime}$ DNI' $M_{2}$ DNI B $B_{2}-B_{1}^{\prime}$ DVA' $M_{1}$ DVA $B_{1}$

where:

DNI is a vector of net income before extraordinary items deflated by the market value of the common stock of firm $i$ at the end of year $t-1$ for the sample firms of the country tested;

\footnotetext{
${ }^{2}$ Meek and Gray (1988) set out the arguments in favor of including value added information in financial reports. The AAA Committee on Accounting and Auditing Measurement (1991) has recommended the inclusion of a value added statement in financial reports, and increased disclosures regarding labor, but to date those recommendations have not been implemented by the Financial Accounting Standards Board.
} 
DVA is a vector of value added deflated by the market value of the common stock of firm $\mathrm{i}$ at the end of year $\mathrm{t}-1$ for the sample firms of the country tested;

$\mathbf{X}_{\mathbf{1}}$ is the matrix of $\mathrm{n}$ observations of a column of ones (for the intercept) and deflated net income: [1 $\mathbf{1}$ DNI];

$\mathbf{X}_{\mathbf{2}}$ is the matrix of $\mathrm{n}$ observations of a column of ones and deflated value added: [1 DVA];

$\mathbf{M}_{\mathbf{1}} \quad$ is a symmetric, idempotent, $\mathrm{n}$ by n matrix: $\left[\mathbf{M}_{\mathbf{1}}=\mathbf{I}_{\mathrm{n}}-\mathbf{X}_{\mathbf{1}}\left(\mathbf{X}_{\mathbf{1}}{ }^{\prime} \mathbf{X}_{\mathbf{1}}\right)^{-1} \mathbf{X}_{1}{ }^{\prime}\right]$;

$\mathbf{M}_{\mathbf{2}} \quad$ is a symmetric, idempotent, $\mathrm{n}$ by n matrix: $\quad\left[\mathbf{M}_{\mathbf{2}}=\mathbf{I}_{\mathrm{n}}-\mathbf{X}_{\mathbf{2}}\left(\mathbf{X}_{\mathbf{2}}{ }^{\prime} \mathbf{X}_{2}\right)^{-1} \mathbf{X}_{2}{ }^{\prime}\right]$;

B is the vector of $\mathrm{k}$ regression coefficients from a regression (with intercept) of annual returns on net income before extraordinary items and value added;

$\mathbf{B}_{\mathbf{1}} \quad$ is the subset of $\mathbf{B}$ containing the coefficient of DVA; and

$\mathbf{B}_{2} \quad$ is the subset of $\mathbf{B}$ containing the coefficient of DNI ].

The following hypothesis (H1) is tested separately for samples from each country. Consistent with arguments derived from shareholder-stakeholder theory, earnings is hypothesized to have relatively better value relevance for samples of companies from the U.S. and U.K. (shareholder cultures) and value added is hypothesized to have better value relevance for Japanese and German companies (stakeholder cultures).

H1 $1_{\mathrm{A}}$ : Earnings (value added) provides relatively better associations with returns than value added (earnings) for samples of companies from shareholder (stakeholder) cultures.

H1 $1_{0}: \quad \Theta=$ B $_{2}^{\prime}$ DNI' $M_{2}$ DNI B $B_{2}-B_{1}^{\prime}$ DVA' $M_{1}$ DVA $B_{1}=0$

$\mathbf{M}_{1}$ and $\mathbf{M}_{2}$ are the "residual maker" matrices for $\mathbf{X}_{1}$ and $\mathbf{X}_{2}$ respectively. $\mathbf{B}_{1}{ }^{\prime} \mathbf{D V A} \mathbf{A}^{\prime} \mathbf{M}_{1}$ therefore represents the residuals when an estimate of returns from a value added model is regressed on net income. The $\mathrm{B}_{1}{ }^{\prime} \mathbf{D V A} \mathbf{A}^{\prime} \mathbf{M}_{\mathbf{1}}$ DVA $B_{1}$ term in equation (1) represents the sum of squares of these residuals. Similarly, the $\mathrm{B}_{2}{ }^{\prime} \mathbf{D N I}^{\prime} \mathbf{M}_{2} \mathbf{D N I}_{2}$ term in equation (1) represents the sum of squared residuals resulting when an estimate of returns from a net income model is regressed on value added. If the $\mathbf{B}_{1}{ }^{\prime} \mathbf{D V A} \mathbf{A}^{\prime} \mathbf{M}_{\mathbf{1}} \mathbf{D V A} \mathrm{B}_{1}$ term is smaller than the $\mathrm{B}_{2}{ }^{\prime} \mathbf{D N I} \mathbf{M}_{\mathbf{2}} \mathbf{D N I} \mathbf{B}_{2}$ term, then the explanatory variable in $\mathbf{M}_{\mathbf{1}}$ (net income) can explain relatively more of any variation in returns explained by value added than value added can explain of the variation explained by net income, and net income has more value relevance. If the $\mathbf{B}_{2}$ ' DNI' $\mathbf{M}_{2}$ DNI $\mathbf{B}_{2}$ term is smaller than the $\mathbf{B}_{1}{ }^{\prime} \mathbf{D V A} \mathbf{A}^{\prime} \mathbf{M}_{1} \mathbf{D V A} \mathrm{B}_{1}$ term, then value added has more value relevance. The Wald $X^{2}$ test, with White's adjustment for heteroscedasticity is applied to $\Theta$ in equation (1) to determine if the relative value relevance of income is significantly different from that of value added. A positive value for $\Theta$ indicates that net income has more relative value relevance, while a negative $\Theta$ indicates more value relevance for value added. The $\overline{\mathrm{R}}^{2}$ statistics from equations (2) and (3) are used in conjunction with the BSS test to indicate the degree of value relevance of the two measures (Biddle, Seow, and Siegel 1995, Black 1998).

$\begin{array}{ll}\operatorname{RTN}_{\mathrm{it}}=\alpha_{0}+\alpha_{1} \mathrm{DVA}_{\mathrm{it}} & +\mathrm{e}_{\mathrm{it}} \\ \mathrm{RTN}_{\mathrm{it}}=\beta_{0}+\beta_{1} \mathrm{DNI}_{\mathrm{it}} & +\mathrm{e}_{\mathrm{it}}\end{array}$

Where

RTN $_{\text {it }}=$ annual return on equity of firm i during year $\mathrm{t}$,

$$
\operatorname{RTN}_{i t}=\frac{P_{i t}-P_{i, t-1}+D_{\text {IV }}}{P_{i, t-1}}
$$

$\mathrm{NI}_{\text {it }}=$ net income before extraordinary items of firm i during year $\mathrm{t}$,

$\mathrm{DNI}_{\mathrm{it}} \quad=\mathrm{NI}_{\mathrm{it}} / \mathrm{MV}_{\mathrm{it}-1}$,

$\mathrm{VA}_{\mathrm{it}} \quad=$ value added of firm i during year $\mathrm{t}$,

$\mathrm{DVA}_{\mathrm{it}} \quad=\mathrm{VA}_{\mathrm{it}} / \mathrm{MV}_{\mathrm{it}-1}$,

$\mathrm{MV}_{\mathrm{it}-1} \quad=$ the market value of the common stock of firm $\mathrm{i}$ at the end of year $\mathrm{t}-1$,

$\mathrm{P}_{\mathrm{it}} \quad=$ the market value per share of the common stock of firm $\mathrm{i}$ at the end of year $\mathrm{t}$,

$\mathrm{DIV}_{\mathrm{it}} \quad=$ dividends of firm $\mathrm{i}$ during year $\mathrm{t}$. 
Dummy variables (not shown) are employed to account for industry effects (Lev 1989). ${ }^{3}$

\section{Relative Value Relevance Across Countries}

Under stakeholder theory, the long-term nature of the value added signal is expected to increase its value relevance in German and Japanese companies compared to Anglo-American companies. Higher degrees of participation in company affairs by stakeholders, including investors, in German and Japanese companies are believed to reduce information asymmetries and enable managers in those countries to use longer investment time horizons.

This is believed allow managers in Germany and Japan greater leeway to build firm-specific skills and capabilities at the expense of current earnings than is allowed to managers in Anglo-American companies who use current earnings as an equity value proxy (Porter 1992). Empirical research by Jacobson and Aaker (1993) shows that the Japanese stock market incorporates information earlier than the U.S. market, which is consistent with the theory that information asymmetries are lower in Japan than in the U.S. Hypotheses derived from stakeholder theory posit that value added is relatively more value relevant in German and Japanese companies than in Anglo-American companies.

Cross-country comparisons are made by comparing the $\mathrm{R}^{2}$ statistics resulting from returns-net income and returns-value added association models for each of the four countries. The significance of these $\mathrm{R}^{2}$ statistics can be analyzed using a Z-statistic (Harris et al. 1994):

$\mathrm{Z}=\frac{\mathrm{R}_{1}^{2}-\mathrm{R}_{2}^{2}}{\sqrt{\sigma_{\mathrm{R}_{1}^{2}}^{2}+\sigma_{\mathrm{R}_{2}^{2}}^{2}}}$

where:

$\mathrm{Z}$ is a random variable distributed approximately standard normal in large samples,

$\mathrm{R}_{1}^{2}$ is the coefficient of determination from the first (country) model tested,

$\mathrm{R}_{2}^{2}$ is the coefficient of determination from the second (country) model tested,

$\sigma_{R_{1}^{2}}^{2}$ is the variance of $R_{1}^{2}$, and

$\sigma_{R_{2}^{2}}^{2}$ is the variance of $R_{2}^{2}$.

The variance of $\mathrm{R}^{2}$ is determined using the procedure described by Cramer (1987).

\section{Incremental Value Relevance Of Wages And Interest Expense}

There is a substantial conflict of economic theory regarding which governance model, German, Japanese, or Anglo-American, results in better utilization of employee stakeholder resources. The valuation implications of this conflict in theory are addressed in the empirical tests in this section. Although both Japanese and German firms fall within the stakeholder model, the methods used to promote investment in firm-specific skills by non-equity stakeholders differs between the two countries, particularly with regard to human capital.

In Germany, a system of sharing control and access to information with stakeholders is designed to motivate them to make firm-specific investments and is credited with providing these companies with a competitive advantage over Anglo-American shareholder-oriented companies (Turnbull 1997). But stakeholder firms of this type are also known to have a bias toward overinvestment on behalf of the non-equity stakeholders which gives rise to inefficiencies that destroy shareholder value (Porter 1992, Sternberg 1996).

\footnotetext{
${ }^{3} \mathrm{D}_{\mathrm{n}=2 \ldots 7}$ is a dummy variable set to one if a firm is a member of a given one-digit SIC industry and set to zero otherwise.
} 
Japanese employees have little German-style voice in important decisions beyond some operating issues on the factory-floor. Limited labor mobility in Japan also restricts their power of exit. Their stakeholder benefits are derived from implicit contracts underlying the seniority promotion and lifetime employment systems. These systems are believed to give Japanese employees a strong incentive to invest in the development of firm-specific skills. In addition, stable shareholding relationships by dominant investors in Japan enhance the credibility of shareholder commitments to the non-equity stakeholders and decrease the possibility of opportunistic behavior by shareholders. Sheard (1994) credits these long-term employment and shareholding relationships with an ability by Japanese companies to generate superior value for equity and non-equity stakeholders.

Employees in Anglo-American companies do not possess power of voice to the extent of German employees and have less job security than Japanese employees. According to stakeholder theory, the failure to provide voice or other ownership-like incentives to non-equity stakeholders in Anglo-American companies fails to align the interests of these stakeholders with the interests of the investors (M.M. Blair 1995:322, Porter 1992). But Rajan and Zingales (1998) show analytically that increased insecurity among stakeholders in shareholder governance firms may encourage them to make greater firm-specific investments than stakeholders in stakeholder governance firms. There is, therefore, a conflict in theory on this point.

Regarding stakeholder compensation to providers of debt capital, Japanese and German companies generally follow the main bank system where interest payments include not only market determined compensation for borrowings as in the U.S. and U.K., but may also include premiums in the nature of insurance or agency payments (Cable 1985, Hoshi 1994). Whether markets view these payments as increasing or decreasing firm value is an empirical question.

Insight into the value relevance of stakeholder compensation under the three systems (German stakeholder, Japanese stakeholder, and Anglo-American shareholder) may be gained by examining the response coefficients for stakeholder compensation in regression models conditioned on income. Lipe (1986) and Wild (1992) demonstrate that incremental information content is gained by disaggregating net income into the components typically reported by U.S. companies. Compensation to firm stakeholders in the form of wages and interest expense may contain incremental value relevant information.

The relationships between returns to shareholders and stakeholder compensation in the form of wages and interest are examined using equations (4) and (5), which are variations of a basic returns-net income model using annual data.

$\mathrm{RTN}_{\mathrm{it}}=\phi_{0}+\phi_{1} \mathrm{DNI}_{\mathrm{it}}+\phi_{2} \mathrm{DWAGE}_{\mathrm{it}}+\mathrm{e}_{\mathrm{it}}$,

where

WAGE $_{\mathrm{it}} \quad=$ employee compensation expense for firm i during year $\mathrm{t}$, and

$\mathrm{DWAGE}_{\mathrm{it}}=\mathrm{WAGE}_{\mathrm{it}} / \mathrm{MV}_{\mathrm{it}-1}$.

$\mathrm{RTN}_{\mathrm{it}}=\gamma_{0}+\gamma_{1} \mathrm{DNI}_{\mathrm{it}}+\gamma_{2} \mathrm{DINT}_{\mathrm{it}}+\mathrm{e}_{\mathrm{it}}$,

where

$\mathrm{INT}_{\text {it }} \quad=$ interest expense for firm i during year $\mathrm{t}$, and

$\mathrm{DNT}_{\mathrm{it}} \quad=\mathrm{INT}_{\mathrm{it}} / \mathrm{MV}_{\mathrm{it}-1}$.

Dummy variables (not shown) are employed to account for industry effects (Lev 1989). ${ }^{4}$ This basic model may be derived as the first differences of an equation where price is equal to book value plus other information not included in accounting book values (Easton and Harris 1991). ${ }^{5}$

\footnotetext{
${ }^{4} \mathrm{D}_{\mathrm{n}=2 \ldots . .7}$ is a dummy variable set to one if a firm is a member of a given one-digit SIC industry and set to zero otherwise.
} 
The earnings response coefficients in equations (4), $\phi_{1}$, and (5), $\gamma_{1}$, capture the relation between returns and firm's profit net of the effect of wages (equation 4) and interest (equation 5). The regression coefficients for wages and interest expense, $\phi_{2}$ (equation 4) and $\gamma_{2}$ (equation 5), represent the difference between the valuation information in these components versus that in the other components of earnings (Frisch and Waugh 1933). Consistent with prior components research, expenses in this model are defined as negative values. The coefficients for wages and interest may be positive, zero, or negative. If the incremental information is interpreted by investors as representing investments in growth or productivity through stakeholder compensation, the coefficients could be negative (Amir and Lev 1996, Lev and Sougiannis 1996). A positive sign would be consistent with investors anticipating excessive payments to these stakeholders. Response coefficients not significantly different from zero indicate that investors do not view these items differently from the other components of net income. The following two hypotheses, $\mathbf{H} 2$ and $\mathbf{H 3}$, are tested separately for each of the four countries.

$\mathbf{H 2}_{\mathrm{A}}$ : Employee compensation expense is incrementally value relevant beyond net income.

H2 $2_{0}: \quad \phi_{2}=0$.

$\mathbf{H 3}_{\mathrm{A}}$ : Interest expense is incrementally value relevant beyond net income.

$\mathbf{H 3}_{0}: \quad \gamma_{2}=0$.

$\mathbf{H} \mathbf{2}_{\mathbf{0}}-\mathbf{H} \mathbf{3}_{\mathbf{0}}$ examine the value relevance of the individual stakeholder components, wages and interest expense, beyond net income. These hypotheses are tested by examining whether the $t$-value for each of the compensation components coefficients in equations (4) and (5) , $\phi_{2}$ and $\gamma_{2}$, is significantly different from zero. The hypotheses are nondirectional, which reflects the conflicts in economic theory regarding the benefits to shareholders of stakeholder compensation under stakeholder and shareholder governance systems. These tests are performed separately for each country on a year-by-year and on a pooled basis. However, because of the possibility that the standard errors of these regression coefficients may be biased due to cross-sectional correlation, the results of these tests focus on crosstemporal $t$-statistics based on the mean value of the separate yearly coefficients divided by their standard errors (Chaney and Jeter 1994, Ali 1994, Easton and Harris 1991, Rayburn 1986).

\section{Investments In Intangible Stakeholder Assets}

Significant negative coefficients for stakeholder compensation costs (which are expressed as negative values) in the incremental value relevance tests are consistent with the creation of intangible assets which add to the value of the firm (Amir and Lev 1996, Lev and Sougiannis 1996). An indication of the longevity of those assets can be gained by estimating their annual amortization rates. Assuming an efficient market, the value of those intangibles would be included in the market value of the firm even though they are excluded from book value. The relationship between these intangibles and market value can be derived from a valuation of earnings model (Easton 1998, Easton, Eddey, and Harris 1993).

$\mathrm{MKBV}_{\text {it }}=\varphi_{0}+\varphi_{1} \mathrm{NIBV}_{\text {it }}+\varphi_{2}$ WAGEBV $_{\text {it }}+\varphi_{3}$ INTBV $_{\text {it }}+e_{i t}$

where, $\mathrm{MKBV}_{\mathrm{it}}=\mathrm{MV}_{\mathrm{it}} / \mathrm{BV}_{\mathrm{it}}, \mathrm{NIBV}_{\mathrm{it}}=\mathrm{NI}_{\mathrm{it}} / \mathrm{BV}_{\mathrm{it}}$, WAGEBV $\mathrm{W}_{\mathrm{it}}=\mathrm{WAGE} / \mathrm{BV}_{\mathrm{it}}, \mathrm{INTBV}_{\mathrm{it}}=\mathrm{INT}_{\mathrm{it}} / \mathrm{BV}_{\mathrm{it}}$, and $\mathrm{BV}_{\mathrm{it}}=$ the book value of equity for firm $\mathrm{i}$ at the end of year t. Dummy variables (not shown) are employed to account for industry effects. ${ }^{6}$

\footnotetext{
${ }^{5}$ The relation between the price and book value $(\mathrm{BV})$ may be expressed as: $\mathrm{P}_{\mathrm{i}, \mathrm{t}}=\mathrm{BV}_{\mathrm{i}, \mathrm{t}}+\mathrm{u}_{\mathrm{i}, \mathrm{t}}$. Taking first differences, the change in price is $\Delta \mathrm{P}_{\mathrm{i}, \mathrm{t}}=\Delta \mathrm{BV}_{\mathrm{i}, \mathrm{t}}+\mathrm{u}_{\mathrm{i}, \mathrm{t}}$. Where the clean surplus relationship applies: $\Delta \mathrm{BV}_{\mathrm{i}, \mathrm{t}}=\mathrm{NI}_{\mathrm{i}, \mathrm{t}}-\mathrm{DIV}_{\mathrm{i}, \mathrm{t}}$. Therefore,

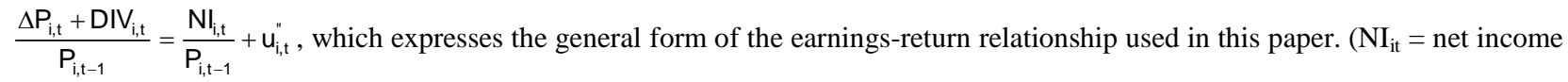
of firm i during year $\mathrm{t}$ ).

${ }^{6} \mathrm{D}_{\mathrm{n}=2 \ldots 7}$ is a dummy variable set to one if a firm is a member of a given one-digit SIC industry and set to zero otherwise.
} 
Assuming that in a cross section of firms, the stock of a firm's intangible assets is proportional to its current investment in intangible assets and that the rate of growth of expenditures in a stakeholder cost $\left(\mathrm{g}_{\mathrm{i}}\right)$ is constant with a rate of amortization equal to $\rho_{\mathrm{i}}$, the stock of intangible asset i may be represented as (Ben-Zion 1978)

$$
\sum_{\mathrm{k}=1}^{\infty}\left(1-\rho_{\mathrm{i}}\right)^{\mathrm{k}} \text { Current Stakeholder Cost } \cdot \frac{1}{\left(1+g_{\mathrm{i}}\right)^{\mathrm{k}}}
$$

Simplifying equation (10), the coefficients $\varphi_{2}$ and $\varphi_{3}$ in equation (9) may be approximated as

$$
\varphi_{\mathrm{i}}=\frac{1}{\rho_{\mathrm{i}}+g_{\mathrm{i}}}-1 \quad \mathrm{i}=2,3 \text {. }
$$

Amortization rates are provided for wages and interest separately for each of the four countries.

\section{DATA SAMPLE}

Annual firm data for the years 1992-1998 for each variable in this study are collected from the Worldscope Global Access database in the case of firms from Japan, the U.K. and Germany and from Compustat PC Plus for U.S. firms. This study employs consolidated financial information for U.S., U.K., and Germany companies, but unconsolidated (parent-only) information for Japanese companies. Parent-only information is used in the case of Japan because consolidated reporting is relatively new in that country and the information needed to compute value added is generally not available on a consolidated basis. In addition, prior research supports the generally held view that parent-only data provides the basis for most market analysis in Japan (French and Poterba 1991) and that it tends to outperform consolidated information in empirical testing (Sakurai 1988, Darrough and Harris 1991, Hall et al. 1994).

Returns in this paper are defined as the price relative, which is a measure of the rate of return assuming continuous compounding. This measure of returns, rather than market adjusted returns, is frequently used in international research (Jacobson and Aaker 1993, Joos and Lang 1994, Harris et al. 1994, Hall et al. 1994). Other accounting variables in the returns models are deflated by the market value of equity at the beginning of the fiscal year in order to reduce heteroscedasticity (Christie 1987). The variables in the returns-net income models therefore represent capital gains and dividends per dollar of market value on the left side and net income and income components per dollar of market value on the right.

Researchers using U.S. data often measure returns as of three months after the end of the fiscal year in order to allow time for the annual report to be released (Dodd et al. 1984). But reporting lags in the countries sampled in this paper can range from 3 months in the United States and Japan to 8 or 9 months in Germany (Alford et al. 1993). Since report dates vary widely, returns are measured as of year end in this paper, which is consistent with prior international research (King and Langli 1998). In order to avoid disproportionate influences, extreme observations whose absolute value of their studentized residuals exceeds two are removed from the sample (Belsley 1980). Restricting the data by dropping extreme values results in a loss of information, but is consistent with prior research, e.g. Kothari and Zimmerman (1995), Easton and Harris (1991), Rayburn (1986).

\section{ECONOMETRIC ISSUES}

The returns models used in this paper are estimated using ordinary least squares (OLS) under the assumptions of homoscedastic error variances and the absence of cross-sectional correlation. In the presence of heteroscedasticity ordinary least squares estimation is inefficient relative to general least squares. Heteroscedasticity arising from variations in the scale of variables in the returns models is addressed by deflating the explanatory variables by the market value of equity at the beginning of the return period (Christie 1987). For computation of amortization rates, a model is employed which expresses the price to book ratio as a function of return on equity and the deflator is the ending book value of the firm. The presence of heteroscedasticity in the models is tested for using 
White's general heteroscedasticity test (White 1980). In all cases where heteroscedasticity is detected at the $5 \%$ significance level, standard errors of the regression coefficients are determined using White's consistent estimator. ${ }^{7}$

Cross sectional dependencies among the security return residuals may cause bias in the standard errors used for significance testing in this research, although OLS coefficients remain unbiased. Much of the bias in the standard error may due to heteroscedasticity (Bernard 1987), which is diagnosed and corrected for, when necessary, using White's procedure (White 1980). The remaining bias is most severe in samples consisting of companies measured contemporaneously in the same industry. Cross sectional correlation is mitigated where samples of firms with varying measurement dates are taken from a large number of industries (Bernard 1987, Bowen et al. 1987). In this proposed research, about $60 \%$ of the U.K. firms and $21 \%$ of the German firms have non-December 31 year ends. However, Japanese firms tend to report financial information uniformly as of March 31. Approximately 50 two-digit SIC (or equivalent) industries are represented in each country sample, resulting in a sample which is highly diverse across industries (Chaney and Jeter 1994). These factors should tend to mitigate bias in standard errors attributable to crosssectional correlation. In the incremental value relevance tests, conclusions are based on an unbiased cross-temporal $t$ statistic obtained from the mean value of the separate yearly coefficients divided by its standard error (Chaney and Jeter 1994, Ali 1994, Easton and Harris 1991, Rayburn 1986).

Collinearity among the explanatory variables can affect the ability to interpret the significance of individual coefficients in incremental information studies (Christie et al. 1984). A table of correlations of the (deflated) explanatory variables used in the regressions is provided. The condition index procedure is also used to detect collinearity (Belsley et al. 1980). ${ }^{8}$

\section{EMPIRICAL RESULTS}

\section{Preliminary Tests}

Pairwise Pearson correlations between the independent variables used in the relative and incremental value relevance tests reveals two correlations in excess of $50 \%$ between the income and wage variables out of the 28 country-years tested. Five instances of correlations in excess of 50\% are observed between income and interest. Condition index diagnostic statistics in only one country-year exceed 3.5: the condition index for U.S. income and interest is 29.786 in 1998 (a condition index between 10 and 30 is evidence of moderate collinearity) and is 7.586 for income and wages of U.S. companies in that year. However, the results for the U.S. sample in the incremental value relevance tests are generally not significant, and this instance of collinearity does not affect the conclusions. Overall then, multicollinearity does not seem to pose a problem in this study.

Preliminary regression results are presented in Table 1. The regression model represents annual returns regressed on value added and the other components of income which are added back to income to compute value added. Since aggregate income is not present in the model, each of the components is expected to demonstrate "normal" behavior, that is, each of the value added and expense components (which are defined as negative values) is expected to carry a significantly positive coefficient. Table $\mathbf{1}$ indicates that the means of the yearly coefficients for value added are positive and significant at the $1 \%$ level for each country except the U.S., where it is positive and significant at the $10 \%$ level. Wages are also positive and significant for each country at the $1 \%$ level, except for the U.S., where they are not significant at conventional levels. Interest is negative and not significant in the U.S. and positive but not significant in all other countries but Japan, where it is both positive and significant at the 5\% level. Taxes are negative and significant at the 5\% level in all countries other than Japan, where they are positive and not significant. While taxes are an important component of value added, it is likely that they are subject to the

\footnotetext{
${ }^{7}$ Est. $\operatorname{Var}(b)=n\left(X^{\prime} X\right)^{-1} S_{0}\left(X^{\prime} X\right)^{-1}$, where $S_{0}=\frac{1}{n} \sum_{i} e_{i}^{2} x_{i} x_{i}$.

${ }^{8}$ This test is performed beginning with a matrix of explanatory variables $(\mathrm{X})$. $\mathrm{X}^{\prime} \mathrm{X}$ is then scaled so that ones are on the diagonal. The square root of the quotient of the maximum and minimum eigenvalues from this scaled matrix provides a condition index (CI). A CI value between 10 and 30 suggests moderate collinearity, while a value over 30 indicates severe multicollinearity.
} 
measurement errors noted in previous research (Ohlson and Penman 1992, Chaney and Jeter 1994), and will not be examined separately in the present study.

Table 1

Preliminary Regression Results

Model: RTN $_{i t}=\delta_{0}+\delta_{1} \mathrm{DVA}_{\mathrm{it}}+\delta_{2} \mathrm{DWAGE}_{\mathrm{it}}+\delta_{3} \mathrm{DINT}_{\mathrm{it}}+\delta_{4} \mathrm{DTAX}_{\mathrm{it}}+\mathrm{e}_{\mathrm{it}+}$,

where, $\mathrm{DVA}_{\mathrm{it}}=\mathrm{VA}_{\mathrm{it}} / \mathrm{MV}_{\mathrm{it}-1}, \mathrm{DWAGE}$ it $=\mathrm{WAGE}_{\mathrm{it}} / \mathrm{MV}_{\mathrm{it}-1}, \mathrm{DINT} \mathrm{T}_{\mathrm{it}}=I N \mathrm{IT}_{\mathrm{it}} / \mathrm{MV}_{\mathrm{it}-1}$, and DTAX $\mathrm{X}_{\mathrm{it}}=\mathrm{TAX}_{\mathrm{it}} / \mathrm{MV}_{\mathrm{it}-1}$.

Mean of the Cross-Sectional Regression Coefficients, 1992 to 1998

(Expenses are defined as negative numbers)

\begin{tabular}{|c|c|c|c|c|c|c|}
\hline Country & & Intercept & DVA & DWAGE & DINT & DTAX \\
\hline Japan & Mean & -21.491 & 91.067 & 83.921 & 97.779 & -48.436 \\
\hline & $t$-value & -2.794 & 10.431 & 7.942 & 3.019 & -0.754 \\
\hline & $p$-value & 0.049 & 0.000 & 0.001 & 0.039 & 0.493 \\
\hline Germany & Mean & 4.743 & 52.591 & 49.588 & 37.597 & -122.263 \\
\hline & $t$-value & 1.794 & 8.879 & 7.636 & 1.473 & -5.846 \\
\hline & $p$-value & 0.147 & 0.001 & 0.002 & 0.215 & 0.004 \\
\hline & Mean & -2.173 & 36.219 & 32.771 & 6.424 & -376.216 \\
\hline & $t$-value & -0.331 & 6.621 & 5.247 & 0.340 & -14.918 \\
\hline & $p$-value & 0.757 & 0.003 & 0.006 & 0.751 & 0.000 \\
\hline & Mean & -8.617 & 26.664 & 22.627 & -12.354 & -141.600 \\
\hline & $t$-value & -1.938 & 2.213 & 1.877 & -0.566 & -3.556 \\
\hline & $p$-value & 0.125 & 0.091 & 0.134 & 0.601 & 0.024 \\
\hline
\end{tabular}

\section{Tests Of The Relative Value Relevance Of Income And Value Added}

Results of the BSS tests of the relative value relevance of value added and income for the four countries in this study are presented in Table 2. The $\Theta$ statistic is positive for Japan and Germany, which is indicative of more relative value relevance for net income than for value added for firms in these countries. Using pooled data for 1992 through 1998, the Wald chi-square values are significant at the $1 \%$ level for both Japan and Germany. In separate year, by year tests, the chi-square values are significant at the 5\% level in six out of the seven years for Japan, but in only three of the seven years for Germany. The results of the BSS tests in Table $\mathbf{2}$ are supplemented with separate, by-country, $\mathrm{R}^{2}$ statistics for each of the income and value added models. These $\mathrm{R}^{2}$ statistics for cross-temporal (19921998) pooled models are presented in Table 3. For Japan and Germany, income is associated with higher $R^{2}$ statistics than value added and these results are significant at the $1 \%$ level in Japan, and $6.7 \%$ level in Germany. These results do not support the proposition presented in $\mathbf{H} \mathbf{1}_{\mathbf{A}}$ that value added has better value relevance than income for Japanese and German companies (stakeholder cultures).

The sample of firms from the U.K. also produce a positive $\Theta$ statistic in Table 2, which is consistent with better relative value relevance for income than for value added. But the associated Wald chi-square value is significant only at the $11 \%$ level for the U.K. The chi-square values are significant at the $5 \%$ level in only three of the seven years for the U.K. sample. $\mathrm{R}^{2}$ statistics in Table 3 support the superior relative value relevance of income over value added in the U.K. and are significant at the $1 \%$ level for pooled data. $\mathbf{H 1}_{\mathbf{A}}$ is generally supported by the results from U.K. companies.

The U.S. sample produces a negative $\Theta$ statistic, which indicates more value relevance for value added than for net income, and the Wald chi-square statistic is significant at the $1 \%$ level. $\mathrm{R}^{2}$ statistics from Table 3 also indicate 
that value added is more value relevant than income in the U.S. and the difference in $\mathrm{R}^{2}$ statistics is significant at the $1 \%$ level. These results for U.S. companies fail to support $\mathbf{H 1}_{\mathbf{A}}$. The results for the U.S. sample of firms used in this study are consistent with prior research using U.S. data (Riahi-Belkaoui 1993, Riahi-Belkaoui and Picur 1994, Bao and Bao 1998). However, because of the small size of the U.S. sample, the possibility of self-selection bias, and the unexpected performance of the U.S. sample throughout this study, consideration should be given to the possibility that the U.K. sample is more representative of Ango-American companies than the small sample of U.S. companies included in this and the prior studies.

Table 2

Results Of Tests Of The Relative Value Relevance Of Income And Value Added

$$
\begin{aligned}
& \text { Model: } \mathrm{RTN}_{\mathrm{it}}=\beta_{0}+\beta_{1} \mathrm{DNl}_{\mathrm{it}}+\beta_{2} \mathrm{DVA}_{\mathrm{it}}+\mathrm{e}_{\mathrm{it}+}, \\
& \text { where, } \mathrm{DNI}_{\mathrm{it}}=\mathrm{Nl}_{\mathrm{it}} / \mathrm{MV}_{\mathrm{it}-1}, \quad \mathrm{DVA}_{\mathrm{it}}=\mathrm{VA}_{\mathrm{it}} / \mathrm{MV}_{\mathrm{it}-1}
\end{aligned}
$$

\begin{tabular}{|c|c|c|c|c|c|c|c|}
\hline Country & $\mathbf{n}$ & Intercept & DNI & DVA & $\Theta$ & $\begin{array}{l}\text { Wald X' } \\
\text { Statistic }\end{array}$ & $X^{2} p$-value \\
\hline \multirow[t]{3}{*}{ Japan } & 11787 & -22.574 & 81.978 & 7.323 & 274398.140 & 55.609 & 0.000 \\
\hline & $t$-value & -7.731 & 22.569 & 7.690 & & & \\
\hline & $p$-value & 0.0001 & 0.000 & 0.0001 & & & \\
\hline \multirow[t]{4}{*}{ Germany } & 2199 & 14.864 & 38.851 & -1.284 & 76412.528 & 16.70194 & 0.000 \\
\hline & ACOV V. & 49.981 & 32.203 & 0.239 & & & \\
\hline & $t$-value & 2.103 & 6.846 & -2.625 & & & \\
\hline & $p$-value & 0.036 & 0.000 & 0.009 & & & \\
\hline \multirow[t]{4}{*}{ U.K. } & 4918 & -1.402 & 45.882 & 11.845 & 203313.370 & 2.544 & 0.111 \\
\hline & ACOV V. & 7.244 & 48.565 & 1.197 & & & \\
\hline & $t$-value & -0.521 & 6.584 & 10.826 & & & \\
\hline & $p$-value & 0.602 & 0.000 & 0.000 & & & \\
\hline \multirow[t]{4}{*}{ U.S. } & 3304 & -4.627 & -2.590 & 10.625 & -394668.1 & 8.751 & 0.003 \\
\hline & ACOV V. & 13.391 & 33.282 & 3.225 & & & \\
\hline & $t$-value & -1.264 & -0.449 & 5.916 & & & \\
\hline & $p$-value & 0.206 & 0.653 & 0.000 & & & \\
\hline
\end{tabular}

Cross-country comparisons of $\mathrm{R}^{2}$ statistics provided in Table $\mathbf{3}$ are used to assess the relative informativeness of value added and income between countries. Separate comparisons are made between value added and value added, income and income, and value added and income for each combination of countries. Z-statistics are used to evaluate the significance of these comparisons. In tests using pooled data, net income of U.K. companies is more value relevant than either the net income or value added of companies from each of the other countries. Each of these U.K. $Z$-statistics is each significant at the 5\% level. U.K. value added is more informative than Japanese income (7.8\% level) and Japanese value added (1\% level). It is also more informative than German value added (1.6\% level) and U.S. net income ( $1 \%$ level). Overall, the stakeholder theory which proposes that value added has greater value relevance in Japan and Germany than in the U.S. or U.K. is not supported by these tests.

\section{Tests Of The Incremental Value Relevance Of Wages And Interest Expense}

The means of the cross-sectional regression coefficients estimated for equations (4) and (5) for 1992 through 1998 are presented in Table 4. The average coefficient for deflated employee compensation (DWAGE) for the 
Japanese company sample is minus 10.052 and is significant at the 5\% level. This is consistent with the market interpreting the incremental value relevance of wages beyond income in Japan as representing investments in growth or productivity. For German companies the coefficient of DWAGE is lower than the Japanese coefficient (-2.182) and is not statistically significant. The coefficient for DWAGE in the U.K. sample is similar to the results for Japan, minus 7.902, and significant at the 5\% level. The DWAGE coefficient for the U.S. sample is not significant at conventional levels. $\mathbf{H} \mathbf{2}_{\mathrm{A}}$ is thus supported for Japanese and U.K. companies, but not for the German or U.S. samples. The results of these incremental value relevance tests for Japanese firms suggest that Japanese employee compensation is valued more similarly to U.K. shareholder-oriented firms than to German stakeholder firms.

Table 3:

Relative Value Relevance Of Income And Value Added - $\mathbf{R}^{2}$ Tests

Models: $\begin{array}{lll}\mathrm{RTN}_{\mathrm{it}}=\alpha_{0}+\alpha_{1} \mathrm{DNN}_{\text {it }} & +\mathrm{e}_{\mathrm{it}} & (2) \\ \mathrm{RTN}_{\mathrm{it}}=\omega_{0}+\omega_{1} \mathrm{DVA}_{\mathrm{it}} & +\mathrm{e}_{\mathrm{it}} & \text { (3) }\end{array} \quad \mathrm{Z}=\frac{\mathrm{R}_{1}^{2}-\mathrm{R}_{2}^{2}}{\sqrt{\sigma_{\mathrm{R}_{1}^{2}+\sigma_{\mathrm{R}}^{2}}^{2}}}$

$\mathrm{R}_{1}{ }^{2}=\mathrm{R}^{2}$ for the test country in the first column, $\mathrm{R}_{2}{ }^{2}=\mathrm{R}^{2}$ for the test countries in the right columns

\begin{tabular}{|c|c|c|c|c|c|c|c|c|c|c|}
\hline \multirow[t]{2}{*}{ Year } & \multirow[t]{2}{*}{ Model } & & \multicolumn{2}{|c|}{ Japan } & \multicolumn{2}{|c|}{ Germany } & \multicolumn{2}{|c|}{ U.K. } & \multicolumn{2}{|c|}{ U.S. } \\
\hline & & $\mathbf{R}^{2}$ & $\begin{array}{c}(2) \\
\text { DNI } \\
\end{array}$ & $\begin{array}{c}\text { (3) } \\
\text { DVA } \\
\end{array}$ & $\begin{array}{c}(2) \\
\text { DNI } \\
\end{array}$ & $\begin{array}{c}\text { (3) } \\
\text { DVA } \\
\end{array}$ & $\begin{array}{c}(2) \\
\text { DNI }\end{array}$ & $\begin{array}{c}(3) \\
\text { DVA } \\
\end{array}$ & $\begin{array}{c}(2) \\
\text { DNI }\end{array}$ & $\begin{array}{c}\text { (3) } \\
\text { DVA } \\
\end{array}$ \\
\hline \multirow[t]{3}{*}{ JAPAN } & $\begin{array}{c}(2) \\
\text { DNI }\end{array}$ & 0.051 & & 4.652 & & 1.223 & & & 3.519 & \\
\hline & & & & 0.000 & & 0.221 & & & 0.000 & \\
\hline & $\begin{array}{c}(3) \\
\text { DVA } \\
\end{array}$ & 0.015 & & & & & & & & \\
\hline \multirow[t]{4}{*}{ GERMANY } & $\begin{array}{c}(2) \\
\text { DNI }\end{array}$ & 0.066 & 1.105 & 3.844 & & 1.831 & & & 3.362 & 0.079 \\
\hline & & & 0.269 & 0.000 & & 0.067 & & & 0.001 & 0.937 \\
\hline & $\begin{array}{c}(3) \\
\text { DVA }\end{array}$ & 0.036 & & 1.746 & & & & & 1.378 & \\
\hline & & & & 0.081 & & & & & 0.168 & \\
\hline \multirow[t]{4}{*}{ U.K. } & $\begin{array}{c}(2) \\
\text { DNI }\end{array}$ & 0.101 & 4.692 & 8.278 & 2.319 & 4.608 & & 2.621 & 7.106 & 2.760 \\
\hline & & & 0.000 & 0.000 & 0.020 & 0.000 & & 0.009 & 0.000 & 0.006 \\
\hline & $\begin{array}{c}(3) \\
\text { DVA }\end{array}$ & 0.069 & 1.763 & 5.475 & 0.201 & 2.398 & & & 4.549 & 0.330 \\
\hline & & & 0.078 & 0.000 & 0.841 & 0.016 & & & 0.000 & 0.742 \\
\hline \multirow[t]{4}{*}{ U.S. } & $\begin{array}{c}(2) \\
\text { DNI }\end{array}$ & 0.018 & & 0.313 & & & & & & \\
\hline & & & & 0.754 & & & & & & \\
\hline & $\begin{array}{c}(3) \\
\text { DVA } \\
\end{array}$ & 0.065 & 1.218 & 4.541 & & 1.974 & & & 3.841 & \\
\hline & & & 0.223 & 0.000 & & 0.048 & & & 0.000 & \\
\hline
\end{tabular}


The means of the coefficients for deflated interest (DINT) in the models summarized in Table 4 are negative and significant at the $10 \%$ level for U.S. and U.K. companies, but are not significant at conventional levels for Japanese or German companies. There is, therefore, weak support for $\mathbf{H 3}_{\mathbf{A}}$ for the U.S. and U.K. samples, but not for the samples of Japanese or German companies.

Table 4

Incremental Value Relevance Of Wages And Interest Beyond Income

$$
\begin{aligned}
& \text { Model (1): } \mathrm{RTN}_{i t}=\kappa_{0}+\kappa_{1} \mathrm{DNI}_{i t}+\kappa_{2} \mathrm{DWAGE}_{\mathrm{it}}+\mathrm{e}_{\mathrm{it}} \\
& \text { Model (2): } R T N_{\text {it }}=v_{0}+v_{1} D_{\text {NIt }}+v_{3} \text { DINT }_{\text {it }}+e_{\text {it }} \\
& \text { where } \mathrm{DNI}_{\mathrm{it}}=\mathrm{NI}_{\mathrm{it}} / \mathrm{MV}_{\mathrm{it}-1} \text {, } \\
& \mathrm{DWAGE}_{\mathrm{it}}=\mathrm{WAGE}_{\mathrm{it}} / \mathrm{MV}_{\mathrm{it}-1} \text {, and } \\
& \mathrm{DINT}_{\text {it }}=\mathrm{INT}_{\mathrm{it}} / \mathrm{MV}_{\mathrm{it}-1} \text {. }
\end{aligned}
$$

\begin{tabular}{|c|c|c|c|c|c|c|}
\hline \multirow[b]{2}{*}{ Country } & \multirow[b]{2}{*}{ Model } & & \multicolumn{4}{|c|}{$\begin{array}{c}\text { Mean of the Cross-Sectional } \\
\text { Regression Coefficients, } 1992 \text { to } 1998 \\
\text { (Expenses are defined as negative numbers) }\end{array}$} \\
\hline & & & Intercept & DNI & DWAGES & DINT \\
\hline \multirow[t]{6}{*}{ Japan } & (1) & Mean & -20.972 & 95.923 & -10.052 & \\
\hline & & $t$-value & -2.759 & 7.441 & -2.823 & \\
\hline & & $p$-value & 0.051 & 0.002 & 0.048 & \\
\hline & (2) & Mean & -18.577 & 100.720 & & -43.324 \\
\hline & & $t$-value & -2.396 & 9.475 & & -1.599 \\
\hline & & $p$-value & 0.075 & 0.001 & & 0.185 \\
\hline \multirow[t]{6}{*}{ Germany } & (1) & Mean & 8.886 & 60.395 & -2.182 & \\
\hline & & $t$-value & 3.853 & 7.665 & -0.854 & \\
\hline & & $p$-value & 0.018 & 0.002 & 0.441 & \\
\hline & (2) & Mean & 8.188 & 61.737 & & -12.113 \\
\hline & & $t$-value & 2.544 & 8.358 & & -0.379 \\
\hline & & $p$-value & 0.064 & 0.001 & & 0.724 \\
\hline \multirow[t]{6}{*}{ U.K. } & (1) & Mean & 6.227 & 58.537 & -7.902 & \\
\hline & & $t$-value & 0.865 & 6.183 & -3.782 & \\
\hline & & $p$-value & 0.436 & 0.003 & 0.019 & \\
\hline & (2) & Mean & 11.447 & 59.179 & & -50.737 \\
\hline & & $t$-value & 1.839 & 6.007 & & -2.670 \\
\hline & & $p$-value & 0.140 & 0.004 & & 0.056 \\
\hline \multirow[t]{6}{*}{ U.S. } & (1) & Mean & -4.685 & 35.294 & -5.887 & \\
\hline & & $t$-value & -0.997 & 1.847 & -1.863 & \\
\hline & & $p$-value & 0.375 & 0.138 & 0.136 & \\
\hline & (2) & Mean & -3.334 & 39.538 & & -61.246 \\
\hline & & $t$-value & -0.703 & 2.212 & & -2.469 \\
\hline & & $p$-value & 0.521 & 0.091 & & 0.069 \\
\hline
\end{tabular}




\section{SUMMARY AND CONCLUSIONS}

This research performed a partial test of the instrumental validity of the stakeholder model by examining the value relevance of value added relative to income and the incremental value relevance of two stakeholder compensation components of value added, wages and interest. Contrasts between the results relating to the valuation of the wage costs and intangible human capital in the two stakeholder countries, Japan and Germany, are particularly noteworthy. Wages appear to provide more incremental value relevant information in Japan than Germany and intangible human capital appears to provide benefits over a longer period in Japan than in Germany. These results for Japanese companies were more similar to those obtained from the sample of firms from the U.K., where companies generally follow a shareholder model of corporate governance, than to the results from the German stakeholder model companies.

The results obtained from the sample of U.S. firms are quite dissimilar from the results for U.K. companies and may not be representative of the population of U.S. companies. This highlights the difficulty of performing tests in environments where data is limited. As international accounting research proceeds and researchers become more confident of the similarities and differences in accounting environments and business cultures, tests using data from other countries which share key characteristics may provide a useful tool to study issues for which data in a given country is not available.

\section{REFERENCES}

1. Alford, A., J. Jones, R. Leftwich, and M. Zmijewski. 1993. The relative informativeness of accounting disclosures in different countries. Journal of Accounting Research 31 (Supplement): 183-223.

2. Ali, A. 1994. The incremental information content of earnings, working capital from operations, and cash flows. Journal of Accounting Research 32 (Spring): 61-74.

3. Amemiya, T. 1980. Selection of regressors. International Economic Review 21: 331-354.

4. Amir, E. and B. Lev. 1996. Value-relevance of nonfinancial information: The wireless communications industry. Journal of Accounting and Economics 22 (Aug.-Dec.): 3-30.

5. Ballester, M., J. Livnat, and N. Sinha. 1999. Labor costs and investments in human capital. Working paper, New York University, New York, NY.

6. Bao, B. H. and D. H. Bao. 1998. Usefulness of value added and abnormal economic earnings: An empirical examination. Journal of Business Finance \& Accounting 25 (January/March): 251-264.

7. Belsley, D. A., E. Kuh, and R. W. Welsch. 1980. Regression Diagnostics: Identifying Influential Data and Sources of Collinearity. New York: John Wiley \& Sons, Inc., Chap. 3.

8. Ben-Zion, U. 1978. The investment aspect of nonproduction expenditures: An empirical test. Journal of Economics and Business 30 (Spring/Summer): 224-229.

9. Bernard, V. L. 1987. Cross-Sectional Dependence and Problems in Inference in Market-Based Accounting Research. Journal of Accounting Research 25 (Spring): 1-48.

10. Biddle, G. C., G. S. Seow, and A. F. Siegel. 1995. Relative versus incremental information content. Contemporary Accounting Research 12 (Fall): 1-23.

11. Black, E. L. 1998. Which is more value relevant: Earnings or cash flows? A life cycle examination. Working paper, University of Arkansas, Fayetteville, AK.

12. Blair, M. M. 1995, Ownership and Control, The Brookings Institution, Washington, D.C.

13. Bowen, R., D. Burgstahler, and L. Daley. 1987. The incremental information content of accrual versus cash flows. The Accounting Review (October): 723-747.

14. Cable, J. 1985. Capital market information and industrial performance: The role of West German banks. The Economic Journal 95 (March): 118-132.

15. Chaney, P. K. and D. C. Jeter. 1994. The effect of deferred taxes on security prices. The Journal of Accounting, Auditing \& Finance 9 (Winter): 91-116.

16. Christie, A. A. 1987. On cross-sectional analysis in accounting research. Journal of Accounting and Economics 9 (December): 231-258.

17. Christie, A. A., M. D. Kennelley, J. W. King, and T. F. Schaefer. 1984. Testing for incremental information content in the presence of collinearity. Journal of Accounting and Economics 6 (December): 205-217. 
18. Cramer, J. S. 1987. Mean and variance of $\mathrm{R}^{2}$ in small and moderate samples. Journal of Econometrics: 253-266.

19. Darrough, M. N. and T. S. Harris. 1991. Do management forecasts of earnings affect stock prices in Japan? in W. T. Ziemba, W. Bailey, and Y. Hamao eds. Japanese Financial Market Research. Amsterdam: NorthHolland: 197-229.

20. Dodd, P., N. Dopuch, R. Holthausen, and R. Leftwich. 1984. Qualified audit opinions and stock prices: Information content, announcement dates, and concurrent disclosures. Journal of Accounting and Economics 6 (April): 3-38.

21. Donaldson, T. and L. E. Preston. 1995. The stakeholder theory of the corporation: Concepts, evidence, implications. Academy of Management Review 20(1): 65-91.

22. Easton, P. D. 1998. Discussion of revalued financial, tangible, and intangible assets: Association with share prices and non-market-based value estimates. Journal of Accounting Research 36 (Supplement): 235-247.

23. , P. H. Eddey, and T. S. Harris. 1993. An investigation of revaluations of tangible long-lived assets. Journal of Accounting Research 31 (Supplement): 1-38.

24. and T. S. Harris. 1991. Earnings as an explanatory variable for returns. Journal of Accounting Research 29(1): 19-36.

25. Freeman, R. E. 1984. Strategic Management: A Stakeholder Approach. Boston: Pirman/Ballinger (Harper Collins).

26. French, K. R. and J. M. Poterba. 1991. Were Japanese stock prices too high? Journal of Financial Economics 29: 337-363.

27. Greene, W. H. 2000. Econometric Analysis, fourth edition. Upper Saddle River, NJ: Prentice Hall.

28. Hall, C., Y. Hamao, and T. S. Harris. 1994. A comparison of relations between security market prices, returns and accounting measures in Japan and the United States. Journal of International Financial Management and Accounting 5 (February): 47-73.

29. Harris, T. S., M. Lang, and H. P. Möller. 1994. The value relevance of German Accounting measures: An empirical analysis. Journal of Accounting Research 32 (Autumn): 187-209.

30. Hoshi, T. 1994. The economic role of corporate grouping and the main bank system, in The Japanese Firm: The Sources of Competitive Strength, M. Aoki and R. Dore eds. Oxford, U.K.: Oxford University Press.

31. Jacobson, R. and D. Aaker. 1993. Myopic management behavior with efficient, but imperfect financial markets: A comparison of information asymmetries in the U.S. and Japan. Journal of Accounting and Economics 16 (October): 383-405.

32. Joos, P. and M. Lang. 1994. The effects of accounting diversity: Evidence from the European Union. Journal of Accounting Research 32 (Supplement): 141-168.

33. King, R. D. and J. C. Langli. 1998. Accounting diversity and firm valuation. Forthcoming: International Journal of Accounting.

34. Kothari, S. P. and J. L. Zimmerman. 1995. Price and return models. Journal of Accounting \& Economics 20 (September): 155-192.

35. Lev, B. 1989. On the usefulness of earnings and earnings research: Lessons and directions from two decades of empirical research. Journal of Accounting Research 27 (Supplement): 153-192.

36. _ and T. Sougiannis. 1996. The capitalization, amortization and value-relevance of R\&D. Journal of Accounting and Economics 12: 25-46.

37. Lipe, R. C. 1986. The information contained in the components of earnings. Journal of Accounting Research 24 (Supplement): 37-64.

38. MacKie-Mason, J. 1990. Do taxes affect corporate financing decisions? The Journal of Finance 45 (December): 1471-1493.

39. Ohlson, J. A. and S. H. Penman. 1992. Disaggregated accounting data as explanatory variables for returns. Journal of Accounting, Auditing \& Finance 7 (New Series - Fall): 553-573.

40. Penman, S. H. 1992. Return to fundamentals. The Journal of Accounting, Auditing \& Finance 7 (Fall): 465-483.

41. Porter, M. E. 1992. Capital Choices: Changing the Way America Invests in Industry. Washington, D.C.: Council on Competitiveness. 
42. Poterba, J. M. and L. H. Summers. 1992. Time horizons of American firms: New evidence from a survey of CEOs. In Capital Choices: Changing the Way America Invests in Industry. Washington, D.C.: Council on Competitiveness.

43. Rajan, R. and L. Zingales. 1998. Power in a theory of the firm. Quarterly Journal of Economics CXIII (May): 387-432.

44. Rayburn, J. 1986. The association of operating cash flow and accruals with security returns. Journal of Accounting Research 24 (Supplement): 112-133.

45. Renneboog, L. 1999. Corporate Governance Systems; The Role of Ownership, External Finance and Regulation (CEPS Working Document No. 133). Brussels, Belgium: Centre for European Policy Studies.

46. Riahi-Belkaoui, A. 1993. The information content of value added, earnings, and cash flow: US evidence. The International Journal of Accounting 28 (2): 140-146.

47. Riahi-Belkaoui, A. and R. D. Picur. 1994. Net value added as an explanatory variable for returns. Managerial Finance 20 (9): 56-64.

48. Sakurai, H. 1988. Market efficiency and the information content of annual accounting announcements. In The Japanese Stock Market: Pricing Systems and Accounting Information, edited by S. Sakakibara, H. Yamaji, H. Sakurai, K. Shiroshita, and S. Fukuda. New York, NY: Praeger.

49. Sternberg, E. 1996. Stakeholder theory exposed. Corporate Governance Quarterly 2 (March): 4-18.

50. Turnbull. S. 1997. Stakeholder governance: A cybernetic and property rights analysis. Corporate Governance: An International Review 5 (January): 11-23.

51. White, H. 1980. A heteroscedasticity consistent covariance matrix estimator and a direct test of heteroscedasticity. Econometrica 48 (May): 817-838.

52. Wild, J. J. 1992. Stock price informativeness of accounting numbers: Evidence on earnings, book values, and their components. Journal of Accounting and Public Policy 11 (Summer): 119-154.

53. Yoshimori, M. 1996. Whose company is it? The concept of the corporation in Japan and the West. Working paper, Yokohama National University. 